\title{
Correction to: High Precision Monitoring of Radiofrequency Ablation for Liver Using Hyperspectral Imaging
}

\author{
Ramy Abdlaty (1), Mohamed A. Abbass, and Ahmed M. Awadallah \\ Department of Biomedical Engineering, Military Technical College, Cairo, Egypt
}

(published online 6 July 2021)

CORRECTION TO: ANNALS OF BIOMEDICAL ENGINEERING (@ 2021) HTTPS://DOI.ORG/ 10.1007/S10439-021-02797-W

This correction is to change the name of the instrument used in the RF ablation and in Fig. 2.
The original article has been corrected.

Publisher's Note Springer Nature remains neutral with regard to jurisdictional claims in published maps and institutional affiliations.

Address correspondence to Ramy Abdlaty, Department of Biomedical Engineering, Military Technical College, Cairo, Egypt. Electronic mail: ramy.elghwas@mtc.edu.eg

The original article can be found online at https://doi.org/10. 1007/s10439-021-02797-w. 